\title{
Pathogenic diversity of Phytophthora sojae pathotypes from Brazil
}

\author{
Leila Maria Costamilan • \\ Cláudia Cristina Clebsch • \\ Rafael Moreira Soares • \\ Claudine Dinali Santos Seixas • \\ Cláudia Vieira Godoy • \\ Anne Elizabeth Dorrance
}

Accepted: 7 November 2012 / Published online: 22 November 2012

(C) KNPV 2012

\begin{abstract}
Phytophthora root and stem rot has developed in commercial soybean fields since 2006 in Brazil, and cultivars with resistance to this disease have not been targeted for this region. Thus, the Phytophthora sojae pathotypes are expected to have virulence to few if any of the Rps genes. The objectives of this study were to characterize the pathotype diversity of $P$. sojae in Brazil, determine the distribution of the pathogen and predict which Rps genes will be effective and should be used in breeding programs. Isolates were collected in six states (Rio Grande do Sul, Santa Catarina, Paraná, Mato Grosso do Sul, Minas Gerais, and Goiás). The virulence formulae were based on the response of a differential set with 14 Rps genes (1a, $1 \mathrm{~b}, 1 \mathrm{c}, 1 \mathrm{~d}, 1 \mathrm{k}, 2,3 \mathrm{a}, 3 \mathrm{~b}, 3 \mathrm{c}, 4,5,6,7$, and 8). None of the 17 pathotypes found was reported previously. The most common virulence formulas were: 1d, 2, 3c, 4, 5,
\end{abstract}

L. M. Costamilan $(\bowtie) \cdot$ C. C. Clebsch

Centro Nacional de Pesquisa de Trigo (Embrapa Trigo), Empresa Brasileira de Pesquisa Agropecuária (Embrapa), Cx. Postal 451, CEP 99001-970 Passo Fundo, RS, Brazil e-mail: leila@cnpt.embrapa.br

R. M. Soares • C. D. S. Seixas • C. V. Godoy

Centro Nacional de Pesquisa de Soja (Embrapa Soja), Empresa Brasileira de Pesquisa Agropecuária (Embrapa), Cx. Postal 231, CEP 86001-970 Londrina, PR, Brazil

A. E. Dorrance

Department of Plant Pathology, The Ohio State University, 44691-4096, Wooster, OH, USA
6, 7 (octal code 05471 , representing $24 \%$ of the occurrences); 1d, 2, 3b, 3c, 4, 5, 6, 7 (05671, $13 \%$ ); 1b, 1d, 2, 3a, 3c, 4, 5, 6, 7 (25571, $8 \%$ ); and 1d, 3a, 5, $7,8(01123,8 \%)$. Percentages of isolates with a susceptible interaction with each $R p s$ gene was $R p s 1 \mathrm{a}$ (3\%), Rps1b (11\%), Rps1c (3\%), Rps1d (100\%), Rps1k (3\%), Rps2 (86 \%), Rps3a (32\%), Rps3b (19\%), Rps3c (73\%), Rps4 (70\%), Rps5 (89\%), Rps6 (59\%), Rps7 (100\%), and Rps8 (22\%). There was apparently no relationship between pathotypes and origin. Stacking resistance genes Rps $1 \mathrm{a}, R p s 1 \mathrm{~b}$, $R p s 1 \mathrm{c}$, and Rps $1 \mathrm{k}$ with Rps $3 \mathrm{~b}$ or Rps 8 would be highly effective for soybean cultivars targeted for Brazil.

Keywords Glycine max . Phytophthora root rot - Race . Soybean · Variability

\section{Introduction}

Phytophthora root and stem rot (PRR) of soybean [Glycine max (L.) Merr.], caused by Phytophthora sojae Kaufm. \& Gerd., affects susceptible soybean cultivars throughout the growing season. The most characteristic symptom is the discolouration of the lower stem from the soil line, which can affect lateral branches. Economic damage is related to extensive replanting early in the growing season and poor plant stand. Schmitthenner (1999) reported $100 \%$ yield loss on highly susceptible soybean cultivars. Wrather and 
Koenning (2010) considered PRR the second most damaging soybean disease in the USA, with an estimated mean loss of 46,631 million bushels/year from 2001 to 2010.

PRR incidence and severity are related to the presence of inoculum in the field, high soil moisture and susceptibility of the soybean cultivar. Oospores can survive for many years in crop residue and in soil. Zoospores are released when soil is flooded and are attracted to roots of germinating seeds, young roots, or exudates from older roots (Schmitthenner 1999). Soybean cultivars with very low levels of partial resistance or with Rps genes that have been already defeated by the predominant $P$. sojae pathotype are susceptible throughout the growing season (Dorrance et al. 2003; Jackson et al. 2004).

In South America, PRR was first described in Argentina in 1970 (Barreto et al. 1995) and in Brazil in 1995 (Costamilan et al. 2010). Occurrence of the disease remained insignificant and no practical control measures were utilized to manage PRR in Brazil until the 2005/2006 growing season, when great losses were first observed in Rio Grande do Sul and Paraná states (Costamilan et al. 2010). Until the 2011/2012 growing season, PRR was observed in the following Brazilian states: Rio Grande do Sul (RS), Santa Catarina (SC), Paraná (PR), Mato Grosso do Sul (MS), Mato Grosso (MT), Minas Gerais (MG), Goiás (GO), and Tocantins (TO), sometimes only in isolated outbreaks. Since 2009, resistance to PRR is required as an additional description characteristic to seek patent protection on soybean cultivars in Brazil (Brasil 2009).

Commercial Brazilian soybean production started in the 1930s in Rio Grande do Sul, with great expansion during the 1970s, moving to Paraná and then to northern states (Hasse 1996). Soybean breeding programs in Brazil expanded during the 1960s, using US cultivars (e.g., Bienville, Bossier, Bragg, Cobb, Davis, Hale 7, Hardee, Hill, Hood, and Majos), which were well suited to the environmental conditions of south Brazil (Bonato and Bonato 2002). Currently, Brazil is the second largest producer and exporter of soybean in the world with total production of 75.3 million tons produced on 24.2 million hectares during 2010/2011 (USDA 2011; Conab 2011). In the Mercosur countries (Argentina, Brazil, Paraguay, and Uruguay), approximately $70 \%$ of the total cultivated area uses the no-till production system (Derpsch et al. 2010). In southern Brazil, fields which have been cropped continuously to soybean for more than 30 years are common, and have been primarily managed under no-till production systems. Phytophthora sojae was recovered more frequently from the top (0 to $7.5 \mathrm{~cm}$ depth) level of soil collected in four out of five states in the USA under no-till compared to conventional-till cultivation (Workneh et al. 1998). According to Barreto et al. (1998), PRR increased in prevalence and incidence mainly under minimum and no-till systems and developed into major epidemics in the southern part of the soybean area in Argentina.

The most common way to manage PRR is the use of commercial soybean cultivars deployed with dominantly inherited resistance genes (Rps) (Dorrance et al. 2003; 2004; Grau et al. 2004). Phytophthora sojae has physiological specialization, called pathotypes, which impact Rps genes in a gene-for-gene manner. Fourteen Rps genes have been mapped to eight loci in the soybean genome, with an allelic series at two loci: $R p s 1$ (1a, 1b, 1c, 1d, and 1k), Rps2, Rps3 (3a, 3b, and 3c), Rps4, Rps5, Rps6, Rps7 (Dorrance et al. 2004), and Rps8 (Burnham et al. 2003; Gordon et al. 2006). Two novel genes have been described recently, one of them temporarily designated as RpsYu25 (Sun et al. 2011), and the other in the Japanese cultivar Waseshiroge, either allelic to Rps 1, or at a tightly linked locus in a gene cluster (Sugimoto et al. 2011). Among these $R p s$ genes, only five have been deployed to any great extent in soybean cultivars: Rps $1 \mathrm{a}, R p s 1 \mathrm{c}, R p s 1 \mathrm{k}$, Rps3a, and Rps6 (Abney et al. 1997; Dorrance et al. 2003). Rpsla was effective in the USA for approximately 8 years, and $R p s 1 \mathrm{k}$ for almost 20 years (Schmitthenner et al. 1994; Leitz et al. 2000; Dorrance et al. 2003; 2004; Malvick and Grunden 2004).

More than 55 races of $P$. sojae have been designated in the order that they were discovered based on inoculation of differentials. The most common series used eight Rps genes: Rps1a, Rps 1b, Rps $1 \mathrm{c}, R p s 1 \mathrm{~d}$, $R p s 1 \mathrm{k}, R p s 3 \mathrm{a}, R p s 6$, and Rps7. Each novel Rps gene incorporated in the differential series increases the number of possible races as well as the complexity the discussion about the population diversity. Characterization in terms of pathotypes or virulence phenotypes instead of races, and the use of octal codes to compare results, was proposed in order to standardize scientific discussions and to facilitate the reporting of results (Dorrance et al. 2003; Nelson et al. 2008).

Composition of the P. sojae population in terms of compatible reaction on $R p s$ genes was observed to 
have changed over the years, increasing the number of isolates with complex pathotypes (Dorrance et al. 2003). Numerous surveys for pathotype composition of $P$. sojae populations have been carried out primarily in the USA (Schmitthenner et al. 1994; Yang et al. 1996; Leitz et al. 2000; Kaitani et al. 2001; Dorrance et al. 2003; Jackson et al. 2004; Malvick and Grunden 2004; Nelson et al. 2008), as well as in Argentina (Barreto et al. 1995; Gally et al. 2007), and Australia (Ryley et al. 1998). Only the differential with Rps7 had a susceptible reaction (Costamilan et al. 2010) to one isolate from Passo Fundo, RS, in the first study about pathogenicity of $P$. sojae in Brazil. In Argentina, race 1 (virulence for $R p s 7$ ), race 4 (1a, 1c, 7) and a group that did not fit any known race virulence pattern were predominant (Barreto et al. 1998).

Considering that PRR had not caused severe outbreaks until 2006 in Brazil and that the publicly and privately developed soybean cultivars have not been tested as a routine until 2009 , it is very likely that the composition of the native $P$. sojae population has not had any selection pressure and therefore it is expected that there is limited if any variability for pathogenicity. Pathotypes which are highly complex (virulent to many Rps genes) are not expected to be present in Brazil. Thus, the objectives of this study were to characterize the pathotype diversity of $P$. sojae in soybean fields in Brazil, determine the distribution of the pathogen and to identify possible Rps genes which are effective towards this population to be used in soybean breeding programs.

\section{Materials and methods}

Origin of isolates P. sojae was isolated from symptomatic plants collected in fields from the 2006/07 to 2009/ 10 growing seasons. Stems with lesions were washed in tap water, disinfested with $70 \%$ ethanol for 5-10 s, washed in sterile distilled water and placed on a sterile paper to dry. Small pieces of the stem on the edge between diseased and healthy tissue were excised aseptically and placed on the selective medium PBNIC (Schmitthenner and Bhat 1994) with some modifications: $40 \mathrm{ml}$ tomato extract (Elefante ${ }^{\circledR}$, Cargill) replacing V-8 juice in the same volume; $\mathrm{CaCO}_{3} 0.6 \mathrm{~g}$; bacto yeast extract $0.2 \mathrm{~g}$; sucrose $1.0 \mathrm{~g}$; bacto agar $20.0 \mathrm{~g}$; distilled water $1000 \mathrm{ml}$; benomyl $0.0050 \mathrm{~g}$; pentachloronitrobenzene $0.0405 \mathrm{~g}$; iprodione $0.0200 \mathrm{~g}$; neomycin sulphate $0.1000 \mathrm{~g}$; and chloramphenicol $0.0100 \mathrm{~g}$. Cholesterol was not added. The entire disc of agar medium was inverted in the petri plate, covering soybean stem pieces. Plates were incubated in a growth chamber for five days, at $25+-3{ }^{\circ} \mathrm{C}$. Mycelial growths that appeared on the surface of the agar were transferred to petri plates with diluted tomato extract agar (tomato extract $40 \mathrm{ml}$; $\mathrm{CaCO}_{3} 0.6 \mathrm{~g}$; bacto yeast extract $0.2 \mathrm{~g}$; sucrose $1.0 \mathrm{~g}$; bacto agar $20.0 \mathrm{~g}$; and distilled water $1000 \mathrm{ml}$ ). All colonies were examined with a microscope (at $40 \mathrm{x}$ magnification) for characteristic appearance of mycelium and for oospore formation. For each isolate, a singlezoospore isolate was recovered according to the technique described by Schmitthenner and Bhat (1994). Isolates were stored in liquid nitrogen (Tooley 1988) until their inoculation on to the differential series. The identification and origin of the isolates are presented in Table 1.

Inoculation technique The pathotypes were determined by the hypocotyl inoculation technique (Schmitthenner and Bhat 1994), using the slurry obtained by passing two times the 15-day-old mycelia and agar medium (diluted tomato extract agar with $10.0 \mathrm{~g}$ of bacto agar, poured into 9-cm-diameter petri plates) through a $20-\mathrm{ml}$ syringe. With an 18-gauge needle, a slit was made in the hypocotyl approximately $1 \mathrm{~cm}$ below the cotyledons and $5 \mathrm{~mm}$ long in each seedling. With the syringe, 0.2 to $0.4 \mathrm{ml}$ of the slurry was deposited and 15 seedlings for each differential were inoculated. For this study, the following differentials were used: PI 547677 (Rps 1a), PI 547842 (Rps1b), PI 547834 (Rps1c), PI 103091 (Rps1d), Williams 82 (Rps1k), PI 547838 (Rps2), PI 547862 (Rps3a), PI 591509 (Rps3b), L92-7857 (Rps3c), L85-2352 (Rps4), PI 547876 (Rps5), PI 591511 (Rps6), Harosoy (Rps7), and PI 399073 (Rps8). The differentials were obtained from the USDA ARS Soybean Germplasm Collection (R. Nelson, University of Illinois, Urbana, IL) and were increased and maintained at Embrapa Trigo, Passo Fundo, RS. Cultivar BRS 244RR was used as universal suscept. All cultivars were initially tested in three replications, with five seeds of each differential being evaluated per replication for a total of 15 seedlings, planted in plastic cups $(500 \mathrm{ml})$, in a substrate made of pine bark, vermiculite, turf soil, and vegetal charcoal (Tecnomax ${ }^{\circledR}$, Ferticel Ltda.). Fifteen 11-dayold seedlings were inoculated per differential and the plants were incubated in a dew chamber for the next $48 \mathrm{~h}$, at a temperature ranging from 18 to $20^{\circ} \mathrm{C}$, in the 
Table 1 Identification of Phytophthora sojae isolates collected in Brazil from the 2006/07 to 2009/10 growing seasons

\begin{tabular}{|c|c|c|c|c|}
\hline \multirow{2}{*}{$\begin{array}{l}\text { tophthora sojae isolates collect- } \\
\text { ed in Brazil from the } 2006 / 07 \text { to } \\
2009 / 10 \text { growing seasons }\end{array}$} & Code & Place of origin & State $^{\mathrm{a}}$ & Cultivar of origin \\
\hline & Ps $1 / 07$ & Passo Fundo & RS & CD FAPA 220 \\
\hline & Ps $2 / 07$ & Passo Fundo & RS & BRS Charrua RR \\
\hline & Ps $3 / 07$ & Passo Fundo & RS & Genotype (breeding program) \\
\hline & Ps $4 / 07$ & Passo Fundo & RS & PI 398777 \\
\hline & Ps $5 / 07$ & Passo Fundo & RS & PI 416764 \\
\hline & Ps $6 / 07$ & Passo Fundo & RS & PI 423966 \\
\hline & Ps $7 / 07$ & Coxilha & $\mathrm{RS}$ & BRS 245 RR \\
\hline & Ps $8 / 07$ & Coxilha & RS & BRS 256 RR \\
\hline & Ps $9 / 07$ & Ponta Grossa & PR & Not identified \\
\hline & Ps $10 / 08$ & Ronda Alta & RS & BRS 245 RR \\
\hline & Ps $11 / 08$ & Coxilha & RS & BRS 242 RR \\
\hline & Ps $12 / 08$ & Coxilha & RS & BRS 255 RR \\
\hline & Ps $13 / 08$ & Uberaba & $\mathrm{MG}$ & Not identified \\
\hline & Ps $14 / 08$ & Cachoeirinha & $\mathrm{RS}$ & Genotype (breeding program) \\
\hline & Ps $15 / 08$ & Carambeí & PR & NK 2555 \\
\hline & Ps $16 / 08$ & Santo Ângelo & RS & Maradona \\
\hline & Ps $17 / 08$ & Passo Fundo & RS & Not identified \\
\hline & Ps $18 / 08$ & Pelotas & RS & Not identified \\
\hline & Ps $19 / 08$ & Arroio Grande & RS & MSOY 7979 RR \\
\hline & Ps $20 / 08$ & Camaquã & RS & BRS 244 RR \\
\hline & Ps $21 / 08$ & Maracaju & MS & BRS Charrua RR \\
\hline & Ps $22 / 09$ & Pato Branco & PR & NK 7054 RR \\
\hline & Ps $23 / 09$ & Colorado & RS & NK 7054 RR \\
\hline & Ps $24 / 09$ & Castro & PR & NK 3363 \\
\hline & Ps $25 / 09$ & Ipiranga do Sul & RS & BRS 242 RR \\
\hline & Ps $26 / 09$ & Cachoeirinha & RS & BRS Charrua RR \\
\hline & Ps $27 / 09$ & Chapada & RS & Maradona \\
\hline & Ps $28 / 09$ & Sananduva & RS & Fundacep 53 \\
\hline & Ps $29 / 09$ & Marau & $\mathrm{RS}$ & Not identified \\
\hline & Ps $30 / 09$ & Não-Me-Toque & RS & Fundacep 53 \\
\hline & Ps $31 / 09$ & Ijuí & $\mathrm{RS}$ & BRS Charrua RR \\
\hline & Ps $32 / 10$ & Lagoa Vermelha & RS & Fundacep 53 \\
\hline & Ps $33 / 10$ & Campos Novos & $\mathrm{SC}$ & CD 249 RR \\
\hline \multirow{4}{*}{$\begin{array}{l}{ }^{a} \text { Brazilian states: Rio Grande do } \\
\text { Sul (RS), Santa Catarina (SC), } \\
\text { Paraná (PR), Mato Grosso do } \\
\text { Sul (MS), Minas Gerais (MG), } \\
\text { and Goiás (GO) }\end{array}$} & Ps $34 / 10$ & Cachoeira do Sul & $\mathrm{RS}$ & Genotype (breeding program) \\
\hline & Ps $35 / 10$ & Cachoeira do Sul & $\mathrm{RS}$ & Genotype (breeding program) \\
\hline & Ps $36 / 10$ & Cachoeira do Sul & RS & Genotype (breeding program) \\
\hline & Ps $37 / 10$ & Montividiu & GO & Genotype (breeding program) \\
\hline
\end{tabular}

${ }^{\mathrm{a} B r a z i l i a n}$ states: Rio Grande do Sul (RS), Santa Catarina (SC), Paraná (PR), Mato Grosso do Sul (MS), Minas Gerais (MG), and Goiás $(\mathrm{GO})$ dark. Afterwards, the plants were placed in a greenhouse at temperatures ranging from 18 to $28{ }^{\circ} \mathrm{C}$ and under natural light. The number of dead plants was recorded within five to seven days after inoculation. Cultivars with results between 30 and $70 \%$ were tested two or three times more. A differential was scored susceptible if at least $80 \%$ of the plants in the replicate pots died after inoculations (Nelson et al. 2008).

Pathotype evaluation Virulence data were converted into an octal format using the program HabgoodGilmour Spreadsheet (HaGiS), developed by Herrman 
et al. (1999). The HaGiS program quantifies the number of phenotypes, calculates frequency distribution of virulence to specific Rps genes, isolate complexities (the number of differentials in which an isolate has a susceptible interaction), and quantifies the pathogenic diversity with the Shannon index. Octal codes, using a reverse octal system, were established based on incompatible reaction to Rps genes or resistance (0), and on compatible reaction or susceptibility (1) in the following triplets of Rps genes: 1a, 1b, 1c; 1d, 1k, 2; 3a, 3b, $3 \mathrm{c} ; 4,5,6$; and 7, 8. According to the octal nomenclature, a single number was given for each triplet, based on the reaction of each differential, as follows: $000(=0), 100(=1), 010(=2), 110$
$(=3), 001(=4), 101(=5), 011(=6)$, and $111(=7)$. For example, an isolate with the virulence pathotype $1 \mathrm{~d}, 2$, 3a, 7 will be described by the octal code as 05101 (Herrmann et al. 1999; Dorrance et al. 2003; Malvick and Grunden 2004).

\section{Results}

Phytophthora sojae isolates were recovered from 2007 to 2010 from samples collected in 25 counties in six Brazilian states (Table 1, Fig. 1). Thirty-seven isolates were obtained and 17 pathotypes (identified based on the same octal code) were identified with 14
Fig. 1 Distribution of Phytophthora sojae in Brazil. Numbers represent the 25 counties where isolates were collected. Letters represent Brazilian states: Rio Grande do Sul (RS), Santa Catarina (SC), Paraná (PR), Mato Grosso do Sul (MS), Minas Gerais (MG), and Goiás (GO)

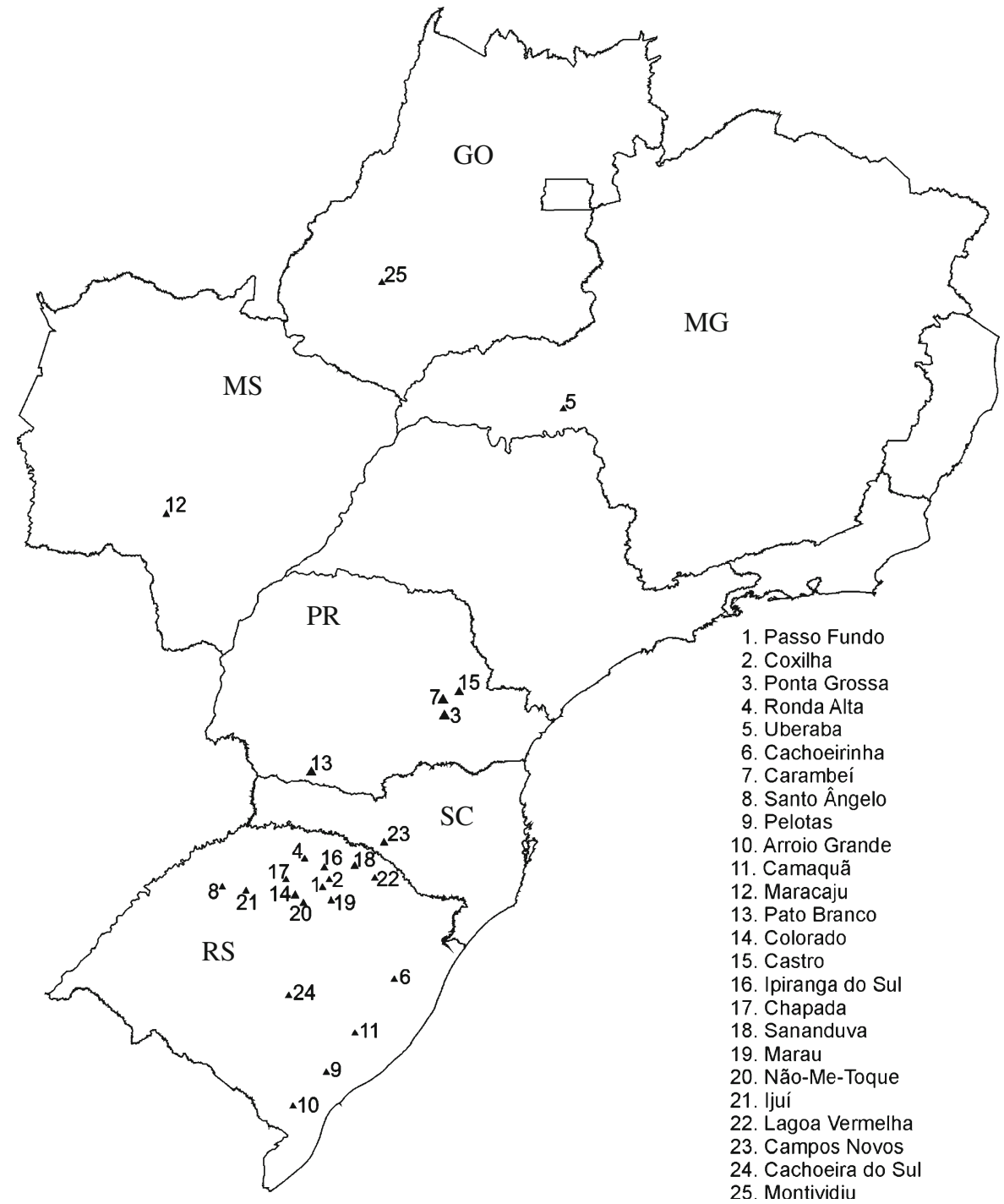


differentials (Table 2). The great majority of the isolates was from Rio Grande do Sul state.

Pathotypes with octal codes 05471 (1d, 2, 3c, 4, 5, 6, 7), 05671 (1d, 2, 3b, 3c, 4, 5, 6, 7), 25571 (1b, 1d, 2, $3 \mathrm{a}, 3 \mathrm{c}, 4,5,6,7)$, and $01123(1 \mathrm{~d}, 3 \mathrm{a}, 5,7,8)$ were the most common, representing $53 \%$ of the total pathotype frequency distribution. Pathotypes 05471 and 05671, collected in Passo Fundo, Ipiranga do Sul, Ijuí, Coxilha, Ronda Alta (RS), Uberaba (MG), Montividiu (GO), and Ponta Grossa (PR), were very similar to each other $(93 \%)$ with the only difference in virulence to Rps3b.

All isolates had a compatible reaction on the differentials containing Rps $1 \mathrm{~d}$ and $R p s 7$, and at least $59 \%$ had a susceptible interaction on the differentials Rps 2 (86\%), Rps3c (73 \%), Rps4 (70\%), Rps5 (89\%), and Rps6 (59\%). Less than $40 \%$ of the isolates had a susceptible interaction on Rps $1 \mathrm{~b}$ (11\%), Rps3a (32\%), Rps3b (19\%), and Rps8 (22\%). Differentials containing genes Rps 1a, Rps 1c, and Rps $1 \mathrm{k}$ were resistant to all but one isolate (Fig. 2).

The pathotype complexity ranged from 3 (isolates from Castro and Pato Branco, PR, and Maracaju, MS) to 10 (isolate from Pelotas, RS). The average complexity value was 6.7 .

\section{Discussion}

This is the first characterization of the virulence pathotypes of $P$. sojae collected in six Brazilian states, using a differential set representing 14 Rps genes. These data are essential for breeding programs, leading to a selection of effective Rps genes for cultivar development. Pathotypes most commonly found had a compatible reaction to eight Rps genes: Rps 1d, Rps2, Rps3a, Rps3c, Rps4, Rps5, Rps6 and $R p s 7$, which are not useful to control PRR in Brazil.
Table 2 Virulence formulae of the pathotypes of Phytophthora sojae isolated from soybean plants in Brazil
${ }^{\text {a }}$ Octal digits were assigned as follows: $000(=0), 100(=1), 010$ $(=2), 110(=3), 001(=4), 101$ (= 5), $011(=6)$, and $111(=7)$, according to the results in triplets of Rps genes: 1a, 1b, 1c; 1d, 1k, 2; 3a, 3b, 3c; 4, 5, 6; and 7, 8. 0 indicates an incompatible reaction, and 1 indicates a compatible reaction on the differentials

${ }^{\mathrm{b}}$ Differential series tested was composed of the following soybean cultivars: PI 547677 (Rps1a), PI 547842 (Rps1b), PI 547834 (Rps 1c), PI 103091 (Rps1d), Williams 82 (Rps1k), PI 547838 (Rps2), PI 547862 (Rps3a), PI 591509 (Rps3b), L92-7857 (Rps3c), L85-2352 (Rps4), PI 547876 (Rps5), PI 591511 (Rps6), Harosoy (Rps7), and PI 399073 (Rps8)

\begin{tabular}{|c|c|c|c|}
\hline Pathotype $^{\mathrm{a}}$ & 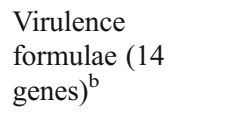 & $\begin{array}{l}\text { No. of } \\
\text { isolates } \\
(\%)\end{array}$ & Origin \\
\hline 05471 & $1 \mathrm{~d}, 2,3 \mathrm{c}, 4,5,6,7$ & $9(24)$ & $\begin{array}{l}\text { Passo Fundo (2), Ipiranga do Sul, Ijuí, } \\
\text { Uberaba, Coxilha (3), Ronda Alta }\end{array}$ \\
\hline 05671 & $\begin{array}{l}1 \mathrm{~d}, 2,3 \mathrm{~b}, 3 \mathrm{c}, 4,5 \\
\quad 6,7\end{array}$ & $5(13)$ & $\begin{array}{l}\text { Montividiu, Coxilha, Passo Fundo (2), Ponta } \\
\text { Grossa }\end{array}$ \\
\hline 25571 & $\begin{array}{l}1 \mathrm{~b}, 1 \mathrm{~d}, 2,3 \mathrm{a}, 3 \mathrm{c}, 4 \\
5,6,7\end{array}$ & $3(8)$ & Cachoeira do Sul (2), Arroio Grande \\
\hline 01123 & $1 d, 3 a, 5,7,8$ & $3(8)$ & Passo Fundo, Chapada, Não-Me-Toque \\
\hline 01021 & $1 d, 5,7$ & $2(5)$ & Castro, Maracaju \\
\hline 05123 & $1 \mathrm{~d}, 2,3 \mathrm{a}, 5,7,8$ & $2(5)$ & Carambeí, Sananduva, \\
\hline 05431 & $1 d, 2,3 c, 4,5,7$ & $2(5)$ & Santo Ângelo, Campos Novos \\
\hline 05573 & $\begin{array}{l}1 \mathrm{~d}, 2,3 \mathrm{a}, 3 \mathrm{c}, 4,5 \\
\quad 6,7,8\end{array}$ & $2(5)$ & Cachoeirinha (2) \\
\hline 57411 & $\begin{array}{l}1 \mathrm{a}, 1 \mathrm{c}, 1 \mathrm{~d}, 1 \mathrm{k}, 2 \\
3 \mathrm{c}, 4,7\end{array}$ & $1(3)$ & Cachoeira do Sul \\
\hline 25771 & $\begin{array}{l}1 \mathrm{~b}, 1 \mathrm{~d}, 2,3 \mathrm{a}, 3 \mathrm{~b} \\
3 \mathrm{c}, 4,5,6,7\end{array}$ & $1(3)$ & Pelotas \\
\hline 05001 & $1 \mathrm{~d}, 2,7$ & $1(3)$ & Pato Branco \\
\hline 05523 & $\frac{1 \mathrm{~d}, 2,3 \mathrm{a}, 3 \mathrm{c}, 5,7}{8}$ & $1(3)$ & Marau \\
\hline 05651 & $\frac{1 d, 2,3 b, 3 c, 4,6}{7}$ & $1(3)$ & Colorado \\
\hline 05401 & $1 d, 2,3 c, 7$ & $1(3)$ & Passo Fundo \\
\hline 05421 & $1 \mathrm{~d}, 2,3 \mathrm{c}, 5,7$ & $1(3)$ & Passo Fundo \\
\hline 05031 & $1 \mathrm{~d}, 2,4,5,7$ & $1(3)$ & Camaquã \\
\hline 05071 & $1 \mathrm{~d}, 2,4,5,6,7$ & $1(3)$ & Lagoa Vermelha \\
\hline Total & & 37 & \\
\hline
\end{tabular}




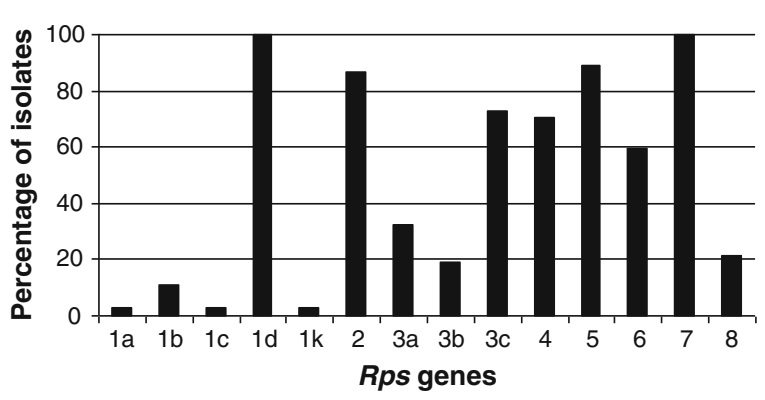

Fig. 2 Percentage of the Phytophthora sojae isolates collected in Brazil with a susceptible interaction with Rps genes

None of the 17 Brazilian pathotypes described in this study was previously reported. The most common pathotypes reported in the USA prior to 1990 included virulence to Rps1a, Rps1c, Rps1d, Rps6, and Rps7; currently, most areas are reporting virulence either to Rps $1 \mathrm{~b}$ and Rps $1 \mathrm{k}$ (Grau et al. 2004). This contrasts to the development of virulence within the $P$. sojae populations in Brazil, in which Rps 1a, 1c and 1k are still highly effective. This fact could indicate that Brazilian and American P. sojae populations do not share the same origin, or that the Brazilian population has had different selection pressure induced by cultivars with $R p s$ gene that were unknowingly deployed.

With this study, there was an increase in virulence to a greater number of Rps genes within the Brazilian isolates ranging from race 1 (vir. 7) to $1 \mathrm{~d}, 3 \mathrm{a}, 6$, and 7 , which were present in $100,39,60 \%$, and $100 \%$ of the P. sojae isolates evaluated, respectively. Barreto et al. (1998) also related an increase in virulence from 1992 to 1997 in Argentina. In the USA, P. sojae populations reportedly have a low incidence of virulence for Rps $1 \mathrm{~d}$ collected in Arkansas (10\%), Illinois (38\%), Ohio (3\%), North Dakota (19\%), Iowa (2\%), and Indiana (14\%) (Yang et al. 1996; Abney et al. 1997; Dorrance et al. 2003; Jackson et al. 2004; Malvick and Grunden 2004; Nelson et al. 2008). In contrast to USA populations which almost all have virulence to Rps $1 \mathrm{a}$, the great majority of Brazilian populations have no virulence response to Rps $1 \mathrm{a}, R p s 1 \mathrm{c}$, or $R p s 1 \mathrm{k}$, which are the most commonly deployed resistance genes in American soybean cultivars (Slaminko et al 2010).

Pathotype surveys are essential for development of breeding strategies to ensure that effective genes will be deployed in cultivars targeted for specific regions. Based on the results of this study, stacking resistance genes $R p s 1 \mathrm{a}, R p s 1 \mathrm{~b}, R p s 1 \mathrm{c}$, and Rps $1 \mathrm{k}$ with $R p s 3 \mathrm{~b}$ or $R p s 8$ would be highly effective for soybean cultivars targeted for Brazil. However, in this process, care should be taken to combine these Rps genes in cultivars with high levels of partial resistance, in order to avoid selection pressure that could lead to a change in the virulence composition of the pathogen (Dorrance and St. Martin 2000).

The P. sojae isolates within the Brazilian population are surprisingly complex with virulence to seven different $R p s$ genes. The variability of $P$. sojae observed in this study is representative of commercial grower fields, especially those located in RS state. In this study, it was observed that large proportions of the $P$. sojae populations had individuals that could cause disease on soybean with a great number of the known Rps genes. This is expected with a long period of continuous soybean production, as occurred in RS, but only if the cultivars have Rps genes. Even the pathotype from Montividiu, $\mathrm{GO}$, a state more recently engaged in soybean commercial production, also had isolates of $P$. sojae with virulence to eight genes (Table 2). The American soybean cultivars used in the development of Brazilian cultivars initially may have been unintentional sources of Rps genes that remained effective for a long time. What types of PRR resistance were present in the cultivars used since 2006 is difficult to identify. In the USA and Australia, the increased selection pressure exerted by Rps genes included in commercial soybean cultivars may have driven the development of a diverse $P$. sojae population with greater genetic variability, and the production of more pathotypes (Schmitthenner et al. 1994; Ryley et al. 1998; Jackson et al. 2004). In Ohio, after a systematic soil survey, it was observed that between 51 and $96 \%$ of the locations had at least one isolate with virulence to commonly deployed Rps genes $1 \mathrm{a}, 1 \mathrm{~b}, 1 \mathrm{c}$, $1 \mathrm{k}, 3 \mathrm{a}$, and 6 (Dorrance et al. 2003). In a 10-year interval, Nelson et al. (2008) also found an increasing numbers of pathotypes (from 4 to 16) infecting plants with the most common resistance genes deployed in the soybean cultivars adapted to North Dakota.

In Argentina, considerable diversity within P. sojae populations from Buenos Aires and Santa Fe provinces suggested rapid evolution, and the higher variability found in Buenos Aires was probably related to a longer evolution compared to the other sites (Gally et al. 2007). The pathogenic diversity identified in the Brazilian $P$. sojae population (Shannon index $=2.53$ ) was smaller than those found among isolates of $P$. sojae recovered from Ohio, which ranged from 2.71 in 1990/1991 to 4.82 in 1997/ 1999 (Dorrance et al. 2003). The difference in pathogenic diversity could be related to the non-intentional 
deployment of soybean cultivars with resistance to PRR in Brazil compared to this state in the USA, which gradually led to a selection of more complex pathotypes.

Based on this limited survey, no relationship was observed between Brazilian isolates and their geographic origins. For a soilborne pathogen that is homothallic, it is expected that isolates from the same region would be similar. However, great variability in pathotype was observed, with different pathotypes collected from the region as well as the same pathotypes recovered from states as far away as RS and MG or GO (Table 2). High intraspecific variability among $P$. sojae isolates from the same geographic origin was also observed in Argentina (Gally et al. 2007) and in the USA, by Dorrance et al. (2003) in Ohio, by Jackson et al (2004) in Arkansas, by Malvick and Grunden (2004) in Illinois, and by Nelson et al. (2008) in North Dakota.

The large adoption of the conservation soil tillage system in Brazilian soybean areas could be part of the cause of the widespread distribution of PRR in the country. No-till has been shown to have impacts on the major concentration of $P$. sojae propagules in the first $7.5 \mathrm{~cm}$ of soil depth (Workneh et al. 1998) and on the development of complex populations of $P$. sojae (Dorrance et al. 2003). In Brazil, some practices used in no-till production could favour the development of PRR: (1) intense traffic of heavy machinery on fields with excessive moisture; (2) double cropping in the same growing season; and (3) cultivation in the rainy season, generating a compacted soil layer between 10 and $20 \mathrm{~cm}$ depth (Franchini et al. 2009). Further studies are necessary to quantify the impact of no-till agriculture on the occurrence of PRR and the development of new $P$. sojae pathotypes in Brazilian soybean fields.

Acknowledgments The authors would like to thank R.L. Nelson from the USDA ARS Soybean Germplasm Collection for seeds of the differential series, to A.M.B dos Santos and A. Lazzarotto for technical assistance, to A. Pasinato for the elaboration of the map, and to I. Brum for the English review. This research was supported by project Embrapa SEG n ${ }^{\circ}$ 02.07.1.002.00.

\section{References}

Abney, T. S., Melgar, J. C., Richards, T. L., Scott, D. H., Grogan, J., \& Young, J. (1997). New races of Phytophthora sojae with Rps1-d virulence. Plant Disease, 81, 653655 .
Barreto, D., Stegman de Gurfinkel, B., \& Fortugno, C. (1995). Races of Phytophthora sojae in Argentina and reaction of soybean cultivars. Plant Disease, 79, 599-600.

Barreto, D., Anderson, T., Gally, M. \& Grijalba, P. (1998). Evaluation of Phytophthora sojae from Argentine soybean fields. (Paper presented at the 7th International Congress of Plant Pathology, Edinburgh). Retrieved July 16, 2012, from http://www.bspp.org.uk/icpp98/6/72.html.

Bonato, E. R., \& Bonato, A. L. V. (2002). Cultivares que fizeram a história da soja no Rio Grande do Sul. Passo Fundo: Embrapa Trigo.

Brasil (2009). Soja (Glycine max (L.) Merrill). Novo formulário descritor. Anexo II - Protocolos para avaliação de reação às doenças. Ministério da Agricultura, Pecuária e Abstecimento. Retrieved July 16, 2012, from http://www.agricultura.gov.br/ vegetal/registros-autorizacoes/protecao-cultivares/formulariosprotecao-cultivares).

Burnham, K. D., Dorrance, A. E., Francis, D. M., Fioritto, R. J., \& St. Martin, S. K. (2003). Rps8, a new locus in soybean for resistance to Phytophthora sojae. Crop Science, 43, 101-105.

Conab (2011). Safras. Séries históricas relativas às safras 1976/77 a 2009/2010 de área plantada, produtividade e produção - Soja. Retrieved October 30, 2011, from http://www.conab.gov.br/ conteudos.php? $\mathrm{a}=1252 \& \mathrm{t}=\&$ Pagina_objcmsconteudos $=3 \# \mathrm{~A}$ objcmsconteudos).

Costamilan, L. M., Soares, R. M., \& Bertagnolli, P. F. (2010). Podridão radicular de fitóftora (Phytophthora sojae). In A. M. R. Almeida \& C. D. S. Seixas (Eds.), Soja: doenças radiculares e de hastes e inter-relações com o manejo do solo e da cultura (pp. 105-126). Londrina: Embrapa Soja.

Derpsch, R., Friedrich, T., Kassam, A. \& Hongwen, L. (2010). Current status of adoption of no-till farming in the world and some of its main benefits. International Journal of Agricultural and Biological Engineering Online. Retrieved from http://ecoport.org/storedReference/559699.pdf.

Dorrance, A. E., \& St. Martin, S. (2000). Phytophthora sojae: Is it time for a new approach? APSnet Features. Retrieved July 17, 2012 from http://www.apsnet.org/publications/ apsnetfeatures/Pages/PhytophthoraSojae.aspx.

Dorrance, A. E., McClure, S. A., \& deSilva, A. (2003). Pathogenic diversity of Phytophthora sojae in Ohio soybean fields. Plant Disease, 87, 139-146.

Dorrance, A. E., Jia, H., \& Abney, T. S. (2004). Evaluation of soybean differentials for their interaction with Phytophthora sojae. Plant Health Progress Online. Retrieved from http:// www.plantmanagementnetwork.org/pub/php/research/2004/ psojae.

Franchini, J. C., Debiasi, H., Sacoman, A., Nepomuceno, A. L., \& Farias, J. R. B. (2009). Manejo do solo para redução das perdas de produtividade pela seca. Londrina: Embrapa Soja. 39p. (Documentos / Embrapa Soja; n.314). Retrieved from http:// www.cnpso.embrapa.br/download/Documentos314.pdf.

Gally, M., Ramos, A. M., Dokmetzian, D., \& Lopez, S. E. (2007). Genetic variability of Phytophthora sojae isolates from Argentina. Mycologia, 99, 813-819.

Gordon, S. G., St. Martin, S. K., \& Dorrance, A. E. (2006). Rps8 maps to a resistance gene rich region on soybean molecular linkage group F. Crop Science, 46, 168-173.

Grau, C. R., Dorrance, A. E., Bond, J., \& Russin, J. S. (2004). Fungal diseases. In H. R. Boerma \& J. E. Specht (Eds.), 
Soybeans: Improvement, production, and uses (pp. 679763). Madison: American Society of Agronomy, Crop Science Society of America, Soil Science Society of America.

Hasse, G. (1996). O Brasil da soja - Abrindo fronteiras, semeando cidades. Porto Alegre: L\&PM.

Herrmann, A., Löwer, C. F., \& Schachtel, G. A. (1999). A new tool for entry and analysis of virulence data for plant pathogens. Plant Pathology, 48, 154-158.

Jackson, T. A., Kirkpatrick, T. L., \& Rupe, J. C. (2004). Races of Phytophthora sojae in Arkansas soybean fields and their effects on commonly grown soybean cultivars. Plant Disease, 88, 345-351.

Kaitani, R. C., Hart, L. P., \& Safir, G. R. (2001). Virulence composition of Phytophthora sojae in Michigan. Plant Disease, 85, 1103-1106.

Leitz, R. A., Hartman, G. L., Pedersen, W. L., \& Nickell, C. D. (2000). Races of Phytophthora sojae on soybean in Illinois. Plant Disease, 84, 487.

Malvick, D. K., \& Grunden, E. (2004). Traits of soybeaninfecting Phytophthora populations from Illinois agricultural fields. Plant Disease, 88, 1139-1145.

Nelson, B. D., Mallik, I., McEwen, D., \& Christianson, T. (2008). Pathotypes, distribution, and metalaxyl sensivity of Phytophthora sojae from North Dakota. Plant Disease, 92, 1062-1066.

Ryley, M. J., Obst, N. R., Irwin, J. A. G., \& Drenth, A. (1998). Changes in the racial composition of Phytophthora sojae in Australia between 1979 and 1996. Plant Disease, 82, 10481054.

Schmitthenner, A. F. (1999). Phytophthora rot. In G. L. Hartman, J. B. Sinclair, \& J. C. Rupe (Eds.), Compendium of soybean diseases (4th ed., pp. 39-42). Saint Paul: APS Press.

Schmitthenner, A. F., \& Bhat, R. G. (1994). Useful methods for studying Phytophthora in the laboratory. Wooster, Ohio
Agricultural Research and Development Center, Special Circular 143. 10p.

Schmitthenner, A. F., Hobe, M., \& Bhat, R. G. (1994). Phytophthora sojae races in Ohio over a 10 -year interval. Plant Disease, 78, 269-276.

Slaminko, T. L., Bowen, C. R., \& Hartman, G. L. (2010). Multi-year evaluation of commercial soybean cultivars for resistance to Phytophthora sojae. Plant Disease, 94, 368-371.

Sugimoto, T., Yoshida, S., Kaga, A., Hajika, M., Watanabe, K., Aino, M., Tatsuda, K., Yamamoto, R., Matoh, T., Walker, D. R., Biggs, A. R., \& Ishimoto, M. (2011). Genetic analysis and identification of DNA markers linked to a novel Phytophthora sojae resistance gene in the Japanese cultivar Waseshiroge. Euphytica, 182, 133-145.

Sun, S., Wu, X. L., Zhao, J. M., Wang, Y. C., Tang, Q. H., Yu, D. Y., Gai, J. Y., \& Xing, H. (2011). Characterization and mapping of RpsYu25, a novel resistance gene to Phytophthora sojae. Plant Breeding, 130, 139-143.

Tooley, P. W. (1988). Use of uncontrolled freezing for liquid nitrogen storage of Phytophthora species. Plant Disease, $72,680-682$.

USDA (2011). Economic Research Service. Soybeans and oil crops: trade. Retrieved October 30, 2011, from http:// www.ers.usda.gov/Briefing/Soybeansoilcrops/trade.htm.

Workneh, F., Yang, X. B., \& Tylka, G. L. (1998). Effects of tillage practices on vertical distribution of Phytophthora sojae. Plant Disease, 82, 1258-1263.

Wrather, J. A., \& Koenning, S. (2010). Soybean disease loss estimates for the United States, 1996-2010. University of Missouri, Delta Research Center. Retrieved from http:// aes.missouri.edu/delta/research/soyloss.stm.

Yang, X. B., Ruff, R. L., Meng, X. Q., \& Workneh, F. (1996). Races of Phytophthora sojae in Iowa soybean fields. Plant Disease, 80, 1418-1420. 